\title{
Influence of Tree Density on Vegetation Composition and Soil Chemical Properties in Savanna Rangeland of Eastern Cape, South Africa
}

\author{
Sive Tokozwayo $^{1^{*}}$ (D) Keletso Mopipi ${ }^{2}$, Eric Cofie Timpong-Jones ${ }^{3}$ \\ ${ }^{1}$ Department of Rural Development \& Agrarian Reform, Döhne Agricultural Development Institute, Stutterheim, Eastern Cape, \\ South Africa \\ ${ }^{2}$ Department of Livestock \& Pasture, University of Fort Hare, Alice, Eastern Cape, South Africa \\ ${ }^{3}$ Livestock and Poultry Research Center, School of Agriculture, College of Basic and Applied Sciences, University of Ghana, Legon, \\ Ghana \\ Email: ^furaluke@gmail.com
}

How to cite this paper: Tokozwayo, S., Mopipi, K. and Timpong-Jones, E.C. (2021) Influence of Tree Density on Vegetation Composition and Soil Chemical Properties in Savanna Rangeland of Eastern Cape, South Africa. Agricultural Sciences, 12, 991-1002. https://doi.org/10.4236/as.2021.1210064

Received: July 27, 2021

Accepted: September 27, 2021

Published: September 30, 2021

Copyright (c) 2021 by author(s) and Scientific Research Publishing Inc. This work is licensed under the Creative Commons Attribution International License (CC BY 4.0).

http://creativecommons.org/licenses/by/4.0/

\begin{abstract}
The proliferation of woody species alters the vegetation structure, leading to loss of rangeland productivity. It aimed to assess the influence of tree density on vegetation and soil chemical properties at three levels of encroachment; open, moderate and dense. Each level of encroachment was replicated 3 times, a $5000 \mathrm{~m}^{2}$ plot was marked per replicate. Four belt transects $200 \mathrm{~m}^{2}$ were placed per plot. Woody species within each belt transect per replicate were identified and recorded to evaluate woody species composition. Grass species composition was assessed using a step point method. Soil was sampled per replicate and analysed for chemical properties. Results showed that $71 \%$ of grasses were increasers and $29 \%$ decreasers. Digitaria eriantha and Eragrostis obtusa were the most dominant species. Vachellia karoo and Aloe ferox were the most dominant woody species. The dense had high nitrogen $(1.48 \%)$ compared to the moderate $(0.23 \%)$ and the open $(0.17 \%)$. Increaser species, soil carbon, soil $\mathrm{pH}$ increased with the increase of tree density. It was concluded that the replacement of highly palatable grasses with inferior ones was due to improper rangeland management practices. It was recommended that land users form rangeland management associations and set up conservation agreements for proper management of resources.
\end{abstract}

\section{Keywords}

Encroachment, Composition, Density, Rangeland 


\section{Introduction}

Savannas are described as biomes with continuous herbaceous vegetation strata and discontinuous trees or shrubs strata [1]. This biome covers $33 \%$ of the surface area of South Africa [2], delivers a wide range of ecosystem services to humans and supports a wide variety of flora and fauna [3]. Tree-grass interactions in rangeland ecosystems have had a lot of attention from researchers [4]. Tree-grass co-existence is a widely and often controversially discussed concept [5]. Walter's two-layer hypothesis has been used to clarify tree-grass eco-existence. Walter's hypothesis proposed that tree roots occupy the surface and deeper layers of the soil whereas grass roots only occur on the top layer [4].

[4] reported that, if the grass layer is over-utilized, it loses its competitive advantage over trees and can no longer use water and nutrients efficiently, thus, leading to a higher water infiltration rate and moving nutrients into the subsoil. This benefits woody plants, allowing them to encroach or dominate in rangeland ecosystems [4]. In South Africa, savanna rangelands ecosystem services have declined as a result of encroachment [6]. Tree encroachment is defined as the thickening of aggressive undesired woody species resulting in an imbalance in the grass to tree ratio which results in a decline in biodiversity and carrying capacity [7]. This phenomenon is associated with the mismanagement of rangelands through overgrazing, suppression or exclusion of fire and the activities of browsers [8].

Tree encroachment is estimated to affect approximately $10-20$ million hectares of South African rangelands [6]. This is expected to deteriorate over time [9]. Tree encroachment suppresses the growth of grasses and other herbaceous species, thus reducing rangeland productivity [7]. Proliferation of trees in savanna rangelands of the Eastern Cape in South Africa is alarming [10]. However, the effect of such encroachment on the condition and productivity of rangelands in the Eastern Cape Province of South Africa has not been documented. The study aimed to assess the effect of increasing tree density on 1) woody plant composition, 2) grass composition, and 3) soil chemical properties.

\section{Material and Methods}

\subsection{Site Description}

The investigation was carried out at Sheshegu communal grazing lands located in Alice Raymond Mhlaba Local Municipality of the Eastern Cape, South Africa (Figure 1). The area is located at coordinates of $32^{\circ} 55^{\prime} 39.30^{\prime \prime S}, 26^{\circ} 49^{\prime} 30.53^{\prime \prime} \mathrm{E}$ with an elevation of $544 \mathrm{~m}$. The region has a semi-arid climate and mean annual precipitation ranges from $450-600 \mathrm{~mm}$, concentrated in the spring and summer [2]. The mean annual temperatures range from $6.3^{\circ} \mathrm{C}$ to $25^{\circ} \mathrm{C}$. Sheshegu communal rangelands are shared by members of the community and grazed continuously with no restrictions on stocking rates. The vegetation in the area has been classified as Bhisho Thornveld vegetation type [2]. The tree layer in the 
study area is dominated by trees and the grass layer. The soils are predominantly mudstone with subordinate sandstone of the Adelaide group and substrate being primary loamy soils [2].

\subsection{Experimental Layout and Sampling}

In October 2014, vegetation and soil sampling were carried out in a 5 ha tree-encroached in Sheshegu communal rangeland. According to [2] Sheshegu communal rangeland forms part of the Bhisho Thornveld. The study site was chosen based on vegetation uniformity and similar land use which was mainly for grazing and browsing. Tree density, which is an estimate of the number of individual trees per plot was used to categorize the study area into three tree-encroachment levels as follows: Open (1425 trees/hectare), moderate (2288 trees/hectare), and dense (3300 trees/hectare). In each tree-encroachment level, a $100 \mathrm{~m} \times 50 \mathrm{~m}$ plot was marked. Four belt transects $(100 \mathrm{~m} \times 2 \mathrm{~m})$ were placed per plot with $15 \mathrm{~m}$ distance apart.

\subsection{Vegetation Sampling}

All woody plant species occurring within each belt transect per tree encroachment level were identified, counted and recorded to evaluate woody plant species composition. Within each belt transect, species composition was evaluated using the step point method along the encroachment gradient [11]. A metal rod was lowered every two steps and herbaceous species nearest to the point were identified. In each belt transect, grasses were identified to species level using the method of [12] other herbaceous plant species were also identified and recorded.

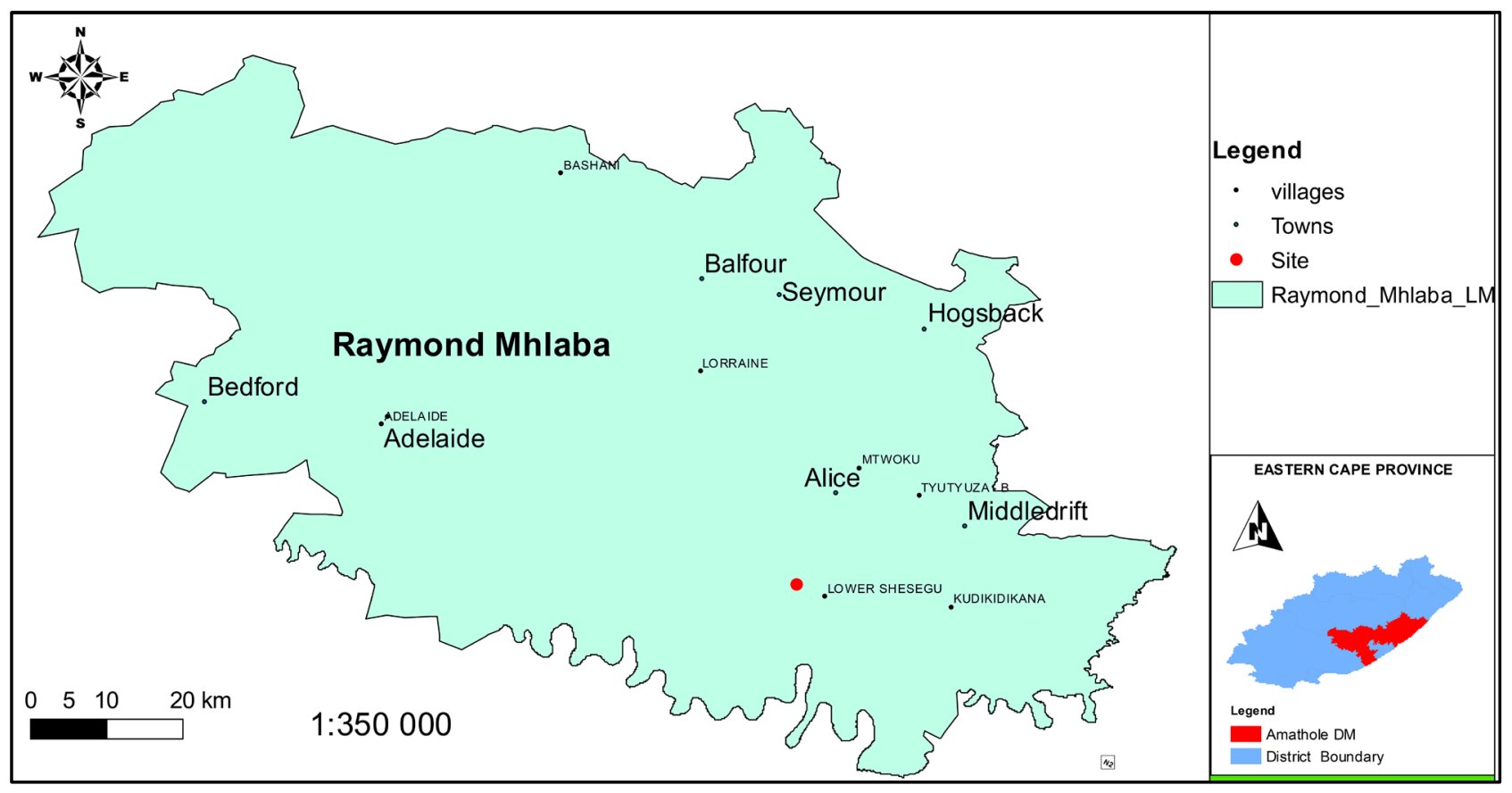

Figure 1. The map of the study site in Raymond Local Municipality under the Amathole District. 
Grass species were later grouped into 1) Decreaser species, 2) Increaser I species and 3) Increaser II species using the procedure of Trollope (1989). Grass species were also grouped into annuals and perennials [13].

\subsection{Soil Sampling and Analysis}

In each belt transect, five soils samples were randomly collected at a depth of 0 $10 \mathrm{~cm}$. Soil samples were oven-dried for 48 hours at $60^{\circ} \mathrm{C}$ and milled to pass through a $2 \mathrm{~mm}$ sieve. Soil samples were analysed for macro-elements as nitrogen $(\mathrm{N})$, magnesium $(\mathrm{Mg})$, potassium $(\mathrm{K})$, phosphorus $(\mathrm{P})$ and soil organic carbon $(\mathrm{OC})$, microelements zinc $(\mathrm{Zn})$, manganese $(\mathrm{Mn})$, copper $(\mathrm{Cu})$, iron $(\mathrm{Fe})$ and soil $\mathrm{pH}$. Available soil $\mathrm{P}, \mathrm{Mg}$ and $\mathrm{K}$ were determined by the Inductively Coupled Plasma analysis of soil with $1 \%$ critic acid [14]. N was determined by using the standard Kjeldahl method using a block digester [15]. OC was analysed using the Waltley-Black method [16]. $\mathrm{Zn}, \mathrm{Mn}$ and $\mathrm{Cu}$ were determined by using Inductively Coupled Plasma in $0.02 \mathrm{M}$ DI-ammonium EDTA (ethylenediaminetetraacetic) acid soil extracts [14]. Soil $\mathrm{pH}$ was determined in $1 \mathrm{M}$ potassium chloride (KCL) [14].

\subsection{Statistical Analysis}

A general linear model procedure of the Statistical Analysis System (SAS, 2009 version) was used to compare the effect of tree encroachment on soil properties along the encroachment gradient [17]. Significant mean differences $(P \leq 0.05)$ between tree encroachment levels were separated using the least significant difference $(\mathrm{LSD})$ at $(\mathrm{P} \leq 0.05)$. Description statistics were employed where appropriate.

\section{Results and Discussion}

\subsection{Woody and Grass Species Composition along Encroachment Gradient}

Seven dominant grass species were identified, $71 \%$ were increasers and $29 \%$ decreasers grass species (Table 1). In terms of grazing value grass species contribute $14 \%$ of medium, $42 \%$ both (high and low) but, all were perennials (Table 1). Digitaria eriantha (open: 34\%, moderate: 23\%, and dense: 15\%), Eragrostis obtusa (open: $21 \%$, moderate: 19\%, and dense: $35 \%$ ) and Eragrostis chloromelas (open: 18\%, moderate: 18\%, and dense: 12\%) showed high percentage of relative abundance compared to other grass species (Table 1). Open had more decreasers species compared to moderate and dense, respectively. This indicated that the frequency of Digitaria eriantha and Themeda triandra decline with the increase of tree density, except for Panicum maximum. Similar results were reported by [18], who demonstrated that an abundance of decreasers species in an openly encroached site is an indicator of the good condition but their proportion decline as encroachment worsens. 
Table 1. Relative abundance (\%), ecological status, grazing value and life form of grasses in open, moderate and dense tree encroached rangeland.

\begin{tabular}{ccccccc}
\hline \multirow{2}{*}{ Species } & $\begin{array}{c}\text { Ecological } \\
\text { Status }\end{array}$ & $\begin{array}{c}\text { Grazing } \\
\text { Value }\end{array}$ & Life form & Open & Moderate & Dense \\
\cline { 5 - 7 } & Increaser II & Low & Perennial & 5 & 8 & 11 \\
\hline Aristida congesta & Delative abundance (\%) \\
Digitaria eriantha & Decreaser & High & Perennial & 34 & 23 & 15 \\
Eragrostis obtusa & Increaser II & Low & Perennial & 21 & 19 & 35 \\
Eragrostis chloromelas & Increaser II & Moderate & Perennial & 18 & 18 & 12 \\
Panicum maximum & Decreaser & High & Perennial & 2 & 10 & 16 \\
Sporobolus africanus & Increaser II & Low & Perennial & 6 & 12 & 3 \\
Themeda triandra & Decreaser & High & Perennial & 14 & 10 & 8 \\
\hline
\end{tabular}

Dense had a high percentage of Aristida congesta and Eragrostis obtuse compared to moderate and open, respectively (Table 1 ). These results indicated that Digitaria eriantha and Themeda triandra declined with an increase in tree density. The gradual decline of these species at dense and moderate tree densities could be a result of continuous grazing, competition between grasses and trees in terms of soil resources. Loss of decreaser species was a clear indication of veld deterioration due to negligence of veld management practices by farmers. Van Oudsthoon (1992) argued that decreasers species can only dominate in good veld condition but could decline because of selective grazing, climate factor, overutilization and manipulation of veld management practices. Overutilization and exclusion of prescribed burning and browsers can accelerate the change of grass species to woodland [19].

These results well compared to that of [4], who states that if grasses are over-utilized they lose its competitive advantage and can no longer use soil resources efficiently. Dense tree density had more Panicum maximum compared to open and moderate, the abundance of this species in dense tree density could be influenced by its tolerance to shading effect. Panicum maximum maintained higher soil resources potentials and was adapted to water stress in the shaded habitat compared to Themeda triandra [20]. This study showed that an increase of tree density favours the abundance of less palatable at the expense highly acceptable. The loss of perennial plants arises from the fact that perennial species are more sensitive to overgrazing. Overutilization of grasses promotes the removal of the apical meristems through overgrazing may limit the regrowth grasses [21].

The gradual replacement of decreasers by increasers at dense and moderate densities could be influenced by veld management practices in particularly uncontrolled grazing and competition of water and soil nutrients. Mismanagement of veld management practices such as uncontrolled grazing might cause a replacement or complete disappearance of palatable species with less palatable ones [22]. Similar results reported by [21], who noted that there is a gradual shift 
of plant species composition consequently strong perennials could be replaced by weak perennials such as Aristida congesta.

\subsection{Woody Species Composition along Encroachment Gradient}

In this study, six dominant woody plant species were identified, $42 \%$ were acceptable (Vachellia karoo, Erehia Rigida and Maytenus polycantha) and 58\% unacceptable (Grewia occidentalis, Diospyros lycioides, Aloe ferox, Coddia rudis and Lucas capensis) to browsers (Table 2). Unacceptable woody plant species might increase in their abundance and such can result in reduced carrying capacity. [23] demonstrated that survival of unpalatable woody species could lead to more recruitment. [24] suggested that tree management must be the main focus, rather than financial benefits of the controlled woody plants.

Vachellia karoo (open: 46.0, moderate: 62.2, dense: 63.8) was dominant species followed by Aloe ferox (open: 6.0, moderate: 1.5, dense: 3.3 ) and Coddia rudis (open: 4.3, moderate: 2.0, dense: 4.5), respectively. Mean abundance of Aloe ferox and Coddia rudis were significantly different whereas Vachellia karoo was not different. Abundance of Vachellia karoo across all levels of tree densities could be caused by climatic factors such as drought and rangeland management practices. [25] demonstrated that overgrazing and frequent burning of grasses have a positive influence on the recruitment of Acacia species and scarifying of woody plant seed through fire. Rainfall availability may also play a major role in the colonization of woody plants [26].

The proliferation of woody plants in communal grazing lands may have influenced by free access to rangeland resources. Moreover, [25] suggested that increased colonies of woody plants may be ascribed to low densities of grasses competing against trees. High grazing pressure due to uncontrolled grazing is the key determinant of trees invasion because it creates an opportunity for colonization, thus, permitting woody recruitment in grass-dominated ecosystem.

\subsection{Soil Chemical Properties along the Encroachment Gradient}

Dense had high concentration of nitrogen (1.48\%) followed by moderate $(0.23 \%)$

Table 2. Mean \pm SE abundance of common woody species in open, moderate and dense tree encroached rangeland.

\begin{tabular}{cccccc}
\hline Species & Acceptability & Thorns & Open & Moderate & Dense \\
\hline Vachellia karoo & + & + & $46.0 \pm 3.3^{\mathrm{a}}$ & $62.2 \pm 3.3^{\mathrm{a}}$ & $63.8 \pm 3.3^{\mathrm{b}}$ \\
Aloe ferox & - & + & $6.0 \pm 1.4^{\mathrm{a}}$ & $1.5 \pm 1.4^{\mathrm{c}}$ & $3.3 \pm 1.4^{\mathrm{b}}$ \\
Coddia rudis & - & - & $4.3 \pm 1.4^{\mathrm{a}}$ & $2.0 \pm 1.4^{\mathrm{b}}$ & $4.5 \pm 1.4^{\mathrm{a}}$ \\
Lucas capensis & - & - & $4.5 \pm 1.0^{\mathrm{a}}$ & $2.7 \pm 1.0^{\mathrm{b}}$ & $2.5 \pm 1.0^{\mathrm{b}}$ \\
Erehia rigida & + & - & $3.3 \pm 1.3^{\mathrm{a}}$ & $1.0 \pm 1.3^{\mathrm{b}}$ & $4.0 \pm 1.3^{\mathrm{a}}$ \\
Maytenus polycantha & + & + & $2.2 \pm 2.4^{\mathrm{b}}$ & $3.0 \pm 2.4^{\mathrm{a}}$ & $2.0 \pm 2.4^{\mathrm{b}}$ \\
\hline
\end{tabular}

Different superscript in a row denote significant differences at $(\mathrm{P}<0.05)$, Plus $(+)$ denotes acceptability and presence of thorns, Minus denotes unacceptability and absence of thorns. 
and open $(0.17 \%)$ respectively. This study showed that soil nitrogen increases with an increase in tree density. Dense was significantly different compared to open tree density (Table 3). In agreement with [27], who reported high nitrogen concentration at dense habitat was double compared to open habitat. The abundance of soil nitrogen at dense could be attributed by triggered by in all encroached sites were dominated by the leguminous tree (Vachellia karoo). Correspond with [19], who stated that Vachellia karoo previous known as Acacia karoo can fix nitrogen, in so doing Vachellia brings additional nitrogen into soil ecosystem.

Table 3 \& Table 4 indicated that there was a positive relationship between soil $\mathrm{pH}$ and nitrogen. Soils with acid ranged between 5 to $7 \mathrm{pH}$ tend to have more nitrogen because such soil $\mathrm{pH}$ favours soil microbial activities and nitrogen fixation [28]. Open had less concentration of soil organic carbon (1.03\%) compared to moderate $(1.20 \%)$ and dense $(1.27 \%)$ tree densities, respectively. Soil carbon showed no significant difference in all levels of tree densities. Soil carbon content could be influenced by the quantity of litter and rainfall, which plays a significant role in soil organic matter accumulation. [29] demonstrated that soil carbon increases from open to dense tree densities. Densely encroached tends to have high soil moisture and the accumulation of dead materials as opposed open tree density [19]. Open rangeland had fewer trees and such allow grazing animal to freely, as results of uncontrolled grazing grass layers were very sparse. Overutilization of rangeland resources through uncontrolled grazing had a potential of reducing soil carbon because it's of impact on grass sward [30].

Open rangeland had high phosphorous concentration measured at $24.0 \mathrm{mg} / \mathrm{kg}$

Table 3. Effect of tree encroachment on macro elements and soil organic matter in open, moderate and dense tree encroached rangeland.

\begin{tabular}{cccccc}
\hline BE-Level & $\begin{array}{c}\text { Nitrogen } \\
(\%)\end{array}$ & $\begin{array}{c}\text { Organic } \\
\text { Carbon }(\%)\end{array}$ & $\begin{array}{c}\text { Potassium } \\
(\mathrm{mg} / \mathrm{kg})\end{array}$ & $\begin{array}{c}\text { Phosphorous } \\
(\mathrm{mg} / \mathrm{kg})\end{array}$ & $\begin{array}{c}\text { Magnesium } \\
(\mathrm{mg} / \mathrm{kg})\end{array}$ \\
\hline Open & $0.17 \pm 0.3^{\mathrm{b}}$ & $1.03 \pm 0.5^{\mathrm{a}}$ & $2.10 \pm 0.4^{\mathrm{a}}$ & $24.0 \pm 2.6^{\mathrm{a}}$ & $1.40 \pm 0.5^{\mathrm{a}}$ \\
Moderate & $0.23 \pm 0.3^{\mathrm{b}}$ & $1.20 \pm 0.5^{\mathrm{a}}$ & $1.84 \pm 0.4^{\mathrm{b}}$ & $22.0 \pm 2.6^{\mathrm{a}}$ & $1.50 \pm 0.5^{\mathrm{a}}$ \\
Dense & $1.48 \pm 0.3^{\mathrm{a}}$ & $1.27 \pm 0.5^{\mathrm{a}}$ & $2.20 \pm 0.4^{\mathrm{a}}$ & $18.0 \pm 2.6^{\mathrm{b}}$ & $1.50 \pm 0.5^{\mathrm{a}}$ \\
\hline
\end{tabular}

BE-tree encroachment; Different superscripts across the column indicate significant difference $(\mathrm{P}<0.05)$.

Table 4. Effect of tree encroachment on micro minerals and soil $\mathrm{pH}$ in open, moderate and dense tree encroached rangeland.

\begin{tabular}{cccccc}
\hline BE-Level & $\begin{array}{c}\text { Copper } \\
(\mathrm{mg} / \mathrm{kg})\end{array}$ & $\begin{array}{c}\text { Iron } \\
(\mathrm{mg} / \mathrm{kg})\end{array}$ & $\begin{array}{c}\text { Manganese } \\
(\mathrm{mg} / \mathrm{kg})\end{array}$ & $\begin{array}{c}\text { Zinc } \\
(\mathrm{mg} / \mathrm{kg})\end{array}$ & $\begin{array}{c}\mathrm{pH} \\
(\mathrm{KCL})\end{array}$ \\
\hline Open & $2.4 \pm 0.3^{\mathrm{a}}$ & $123.0 \pm 5.2^{\mathrm{a}}$ & $243.0 \pm 14.2^{\mathrm{a}}$ & $0.85 \pm 0.2^{\mathrm{a}}$ & $5.4 \pm 0.3^{\mathrm{a}}$ \\
Moderate & $1.6 \pm 0.3^{\mathrm{b}}$ & $117.0 \pm 4.3^{\mathrm{a}}$ & $228.0 \pm 14.2^{\mathrm{a}}$ & $0.99 \pm 0.2^{\mathrm{a}}$ & $5.9 \pm 0.3^{\mathrm{a}}$ \\
Dense & $1.4 \pm 0.3^{\mathrm{b}}$ & $8.9 \pm 1.3^{\mathrm{b}}$ & $160.0 \pm 7.1^{\mathrm{b}}$ & $0.82 \pm 0.2^{\mathrm{a}}$ & $6.0 \pm 0.3^{\mathrm{a}}$ \\
\hline
\end{tabular}

BE-tree encroachment; Different superscripts across the column indicate significant difference $(\mathrm{P}<0.05)$. 
followed by moderate $(22.0 \mathrm{mg} / \mathrm{kg})$, even though dense tree density showed less phosphorous content but were significantly different compared to open and moderate tree densities (Table 3). The study indicated that soil phosphorous concentration declines with an increase in tree density (Table 3). Vachellia karoo tends to have a suppressive effect on the abundance of phosphorous concentration [31]. [32] argued that the concentration of phosphorous can be suppressed by high calcium content in the soil. $V$. karoo have deeper lateral root system and have an advantage over grass sward to access available soil phosphorous in deeper soil profiles [1].

Dense had high potassium content $(2.20 \mathrm{mg} / \mathrm{kg})$ compared to open $(1.84$ $\mathrm{mg} / \mathrm{kg}$ ) and moderate $(2.10 \mathrm{mg} / \mathrm{kg}$ ) tree densities, respectively (Table 3$)$. The concentration of soil potassium showed no clear trend. [33] reported a positive relationship between soil potassium and woody densities. In contradicting the results of [19], who reported that concentrations of potassium tend to be higher under encroached areas. Dense $(1.5 \mathrm{mg} / \mathrm{kg})$ and moderate $(1.5 \mathrm{mg} / \mathrm{kg})$ had the same values for magnesium concentration (Table 3 ). The magnesium concentration showed no clear trend in all levels of tree densities. Soil magnesium could be influenced by soil $\mathrm{pH}$, depth and leaching rate. [34] demonstrated a positive correlation between magnesium soil content and tree density [35] reported individual woody plants tend to have high content of Magnesium and Potassium under dense trees compared to open grasslands trees.

Open had high values of copper $(\mathrm{Cu})$, Iron $(\mathrm{Fe})$, Manganese $(\mathrm{Mn})(\mathrm{Cu} ; 2.4$ $\mathrm{mg} / \mathrm{kg}, \mathrm{Fe} ; 123 \mathrm{mg} / \mathrm{kg}, \mathrm{Mn} ; 243 \mathrm{mg} / \mathrm{kg}$ ) as compared to moderate $(\mathrm{Cu} ; 1.6$ $\mathrm{mg} / \mathrm{kg}$, Fe; $117 \mathrm{mg} / \mathrm{kg}, \mathrm{Mn} ; 228 \mathrm{mg} / \mathrm{kg})$ and dense (Cu; $1.4 \mathrm{mg} / \mathrm{kg} ; \mathrm{Fe} ; 8.9 \mathrm{mg} / \mathrm{kg}$; $\mathrm{Mn} ; 160 \mathrm{mg} / \mathrm{kg}$ ), respectively (Table 4). Dense tree density was significantly different as compared to moderate and open tree densities for iron and manganese. This implies that soil copper, iron and manganese content declines with increase of tree density (Table 4). Zinc showed no clear trend but, moderate $(0.99 \mathrm{mg} / \mathrm{kg})$ had high content of zinc compared to dense $(0.82 \mathrm{mg} / \mathrm{kg})$ and open $(0.85$ $\mathrm{mg} / \mathrm{kg}$ ), respectively (Table 4). [36] reported high values of micro elements at dense tree density as compared to open habitat. [24] argued that falling of tree leaves and animal excretion may contribute to high soil copper and Manganese. [35] argued that acceptable zinc ( $\mathrm{Zn}$ ) concentration for conducive environment for plant growth ranged between 0.15 to $6.56 \mathrm{mg} / \mathrm{kg}$ and such amounts cannot lead plant retardation.

Dense tree density had of value of soil $\mathrm{pH}$ (6.0) as compared to moderate (5.9) and open (5.4) (Table 4). Soil $\mathrm{pH}$ at open and moderate tree densities were slightly acidic as opposed to dense tree density, statistically, soil $\mathrm{pH}$ in all levels of tree densities were not different. [37] reported a high soil $\mathrm{pH}$ values in dense tree site as opposed to open habitat. Acacia species possessed some beneficial properties such as leaf litter which contributes positively to the increase of soil $\mathrm{pH}[38]$. 


\section{Conclusion and Recommendations}

An increase of tree density has resulted in a gradual change of both herbaceous vegetation and soil nutrients. This has led to a gradual decline of grazing capacity and replacement of highly palatable grass species by less palatable ones. An increase of increasers grass species at Sheshegu communal was a clear indication of rangeland deterioration. However, uncontrolled access to rangeland resources, uncontrolled grazing and unplanned burning may influence the vegetation composition and soil properties. It is recommended that farmers should formulate rangeland rules and regulations for proper management of rangeland resources. These rules and regulations should be based on the collective management of encroaching species in terms of density and access to rangeland resources. Correct application of veld management practices such as burning, rational grazing, stocking rate is also recommended for providing good soil cover with edible perennial grass plants that ensure long-term sustainable production with maximum financial return. Further research is needed to explore the influence of veld management practices on the change of vegetation and soil nutrient content in a communal environment.

\section{Acknowledgements}

The authors are indebted to the communal farmers for allowing us to do this research. We are also grateful to University of Fort Hare for the opportunity to conduct this research. We also appreciate the funding from the National Research Foundation (NRF). We are grateful to the Department of Rural Development and Agrarian Reform (i.e. Donhe Agricultural Institute) for the opportunity to allow Mr S. Tokozwayo Sive to write this article. Finally, the support of all technicians, colleagues and field assistants is greatly appreciated.

\section{Conflicts of Interest}

The authors declare no conflicts of interest regarding the publication of this paper.

\section{References}

[1] Mokgosi, R.O., Kellner, K. and Malan, P. (2018) Effects of Tree Encroachment Control in a Communal Area in the Taung Region, North West Province, South Africa.

[2] Mucina, L. and Rutherford, M.C. (2006) The Vegetation of South Africa, Lesotho and Swaziland. South African National Biodiversity Institute, Pretoria, 348-437.

[3] De Groot, R., Brander, L., Van Der Ploeg, S., Bernard, F., Braat, L., Christie, M., Costanza, R., Ghermand, I.A., Hein, L., Kumar, P., Mcvittie, A., Portela, R., Rodriguez, L. and Ten Brink, P. (2012) Global Estimates of the Value of Ecosystems and Their Services. https://doi.org/10.1016/j.ecoser.2012.07.005

[4] Ward, D., Wiegand, K. and Getzin, S. (2013) Walter's Two-Layer Hypothesis Revisited: Back to the Roots. Oecologia, 172, 617-630.

https://doi.org/10.1007/s00442-012-2538-y 
[5] Scheiter, S. and Higgins, S.I. (2007) Partitioning of Root and Shoot Completion and the Stability of Savannas. Journal of American Naturalist, 170, 587-601. https://doi.org/10.1086/521317

[6] Kraaij, T. and Ward, D. (2006) Effects of Rain, Nitrogen, Fire and Grazing on Tree Recruitment and Early Survival in Tree Encroached Savanna. South Africa Plant Ecology, 186, 235-246. https://doi.org/10.1007/s11258-006-9125-4

[7] De Klerk, J.N. (2004) Tree Encroachment in Nambia. Report on Phase One of the Tree Encroachment Research, Monitoring Project, Ministry of Environment and Tourism, Windhoek.

[8] Walker, B., Holling, C.S., Carpenter, S.R. and Kinzing, A. (2004) Resilience, Adaptability and Transformability in Social Ecological Systems. Ecological Social Science, 9, 5-8. https://doi.org/10.5751/ES-00650-090205

[9] Moncrieff, G.R., Scheiter, S., Bond, W.J. and Higgins, S.I. (2014) Increasing Atmospheric $\mathrm{CO}_{2}$ Overrides the Historical Legacy of Multiple Stable Biome in Africa. New Phytologists, 201, 908-915. https://doi.org/10.1111/nph.12551

[10] Belayneh, A. and Tessema, Z.K. (2011) Mechanisms of Tree Encroachment and Its Interconnection with Rangeland Degradation in Semi-Arid Ecosystem: A Review. Journal of Arid Lands, 9, 299-312. https://doi.org/10.1007/s40333-016-0023-X

[11] Vetter, S., Goqwana, W.M., Bond, W.J. and Trollope, W.S.W. (2006) Effects of Land Tenure, Geology and Topography on Vegetation and Soils of Two Grassland Types in South Africa. Journal of Forage and Science, 23, 13-27. https://doi.org/10.2989/10220110609485883

[12] Trollope, W.S.W. (1989) Veld Burning as a Veld Management Practices in Livestock Production. In: Danckwerts, J.E. and Teague, W.R., Eds., Veld Management in the Eastern Cape, Government Printer, Pretoria, 67-73.

[13] Tefera, S., Snyaman, H.A. and Smit, G.N. (2007) Rangeland Dynamics of Southern Ethiopia: (2). Assessments of Woody Vegetation Structure in Relation to Land Use and Distance from Water in Semi-Arid Borana Rangelands. Journal of Environmental Management, 85, 443-452. https://doi.org/10.1016/j.jenvman.2006.10.008

[14] ALASA (1998) Handbook of Feeds and Plants Analysis.

[15] Bremner, J.M. and Breitenbeck, G.A. (1983) A Simple Method of Determination of Ammonium in Semi Micro Kjedahl Analysis of Soil and Plant Material Using a Block Digester. Communication in Soil Science and Plant Analysis, 14, 905-913. https://doi.org/10.1080/00103628309367418

[16] Nelson, D.D. and Somers, L.E. (1982) Total Carbon, Organic Carbon and Organic Matter. Methods of Soil Analysis, Part 2. Chemical and Microbiological Properties, 2nd Edition, Madison, 595-579.

[17] SAS (2009) Institute. Inc. SAS Software. Frame Entry Usage and Reference. Version 8. Cary.

[18] Ward, D. (2005) Do We Understand the Causes of Tree Encroachment in African Savannas? African Journal of Rangeland and Forage Science, 22, 101-105. https://doi.org/10.2989/10220110509485867

[19] Tokozwayo, S. (2016) Evaluating Farmers' Perceptions and the Impact of Tree Encroachment on Herbaceous Vegetation and Soil Nutrients in Sheshegu Communal Rangelands of the Eastern Cape, South Africa. MSc. Thesis, University of Fort Hare, Alice.

[20] Kinyamario, J.I., Trlica, M.J. and Njoka, J.T. (1995) Influence of Tree Shade on Water Status, Gas Exchange and Water Use Efficiency of Panicum Maximum and 
Themeda Triandra in Kenya Savanna. African Journal of Ecology, 33, 114-123. https://doi.org/10.1111/j.1365-2028.1995.tb00787.x

[21] Savadogo, P., Sawudogo, L. and Tiveau, D. (2006) Effects of Grazing Intensity and Prescribed Fire on Soil Physical and Hydrological Properties and Pasture Yield in the Savanna Woodlands of Burkina Faso. Agriculture, Ecosystems and Environment, 11, 80-92. https://doi.org/10.1016/j.agee.2006.05.002

[22] Tessema, Z.K., De Beor, W.F., Baars, R.M.T. and Prins, H.H.T. (2011) Changes in Soil Nutrients, Vegetation Structure and Herbaceous Biomass in Response to Grazing in a Semi-Arid Savanna of Ethopia. Journal of Arid Environments, 75, 662-670. https://doi.org/10.1016/j.jaridenv.2011.02.004

[23] Dangerfield, J.M. and Modukanele, B. (1996) Overcompensation by Acacia Erubescens in Response to Stimulated Browsing. Journal of Tropical Ecology, 12, 905-908. https://doi.org/10.1017/S0266467400010178

[24] Smit, G.N. (2004) An Approach to Tree Thinning to Structure Southern African Savannas for Long-Term Restoration from Bush Encroachment. Journal of Environmental Management, 71, 179-191.

https://doi.org/10.1016/j.jenvman.2004.02.005

[25] Ward, D. and Esler, K.J. (2011) What Are the Effects of Substrate and Grass Removal on Recruitment of Acacia Mellifera Seedlings in a Semi-Arid Environment? African Journal of Plant Ecology, 212, 255-250. https://doi.org/10.1007/s11258-010-9818-6

[26] Jourbert, D.F., Rothauge, A. and Smit, G.N. (2008) A Conceptual Model of Vegetation Dynamics in the Semi-Arid Savannah of Namibia, with Particular Reference to Tree Thickening by Acacia Mellifera. Journal of Arid Environments, 72, 2201-2210. https://doi.org/10.1016/j.jaridenv.2008.07.004

[27] Wiegand, K., Ward, D. and Saltz, D. (2005) Multi-Scale Patterns and Tree Encroachment in an Arid Savanna with a Shallow Soil Layer. Journal of Vegetation Science, 16, 311-320. https://doi.org/10.1111/j.1654-1103.2005.tb02369.x

[28] Mojiri, A., Aziz, H.A. and Ramaji, A. (2012) Potential Decline in Soil Quality Attributes as a Result of Land Use Change in a Hill Slope in Lordgan, Western Iran. Africa Journal of Agricultural Research, 7, 577-582. https://doi.org/10.5897/AJAR11.1505

[29] Retallack, G.J. (2001) Cenozoic Expansion of Grasslands and Climatic Cooling. Journal of Geology, 109, 407-426. https://doi.org/10.1086/320791

[30] Rutherford, M.C. and Powrie, L.W. (2010) Severely Degraded Rangeland: Implications for Plant Diversity from a Case Study in Succulent Karroo, South Africa. Journal of Arid Environments, 74, 692-701.

https://doi.org/10.1016/j.jaridenv.2009.10.013

[31] Vitousek, P.M., Cassman, K., Claveland, C., Crews, T., Field, C.B. and Grimm, N.B. (2002) Towards an Ecological Understanding of Biological Nitrogen Fixation. Biogeomechemistry, 57, 1-45. https://doi.org/10.1007/978-94-017-3405-9 1

[32] Foth, D.H. (1990) Fundamentals of Soil Science. 8th Edition, John Wiley and Sons Incorporated, Hoboken.

[33] Zhang, Y., Xu, Z., Jiang, D. and Jiang, Y. (2013) Soil Exchangeable Base Cations along a Chronosequence. Caragana Microphylla Plantation in a Semi-Arid Sandy Land, China. Journal of Arid Lands, 5, 42-50.

https://doi.org/10.1007/s40333-013-0140-8

[34] Okpamen, S.U., Ilori, E.G., Agho, I., Nkechika, A., Maidoh, F.U. and Okonjo, P.N. 
(2013) Influence of Depths and Soil PH on Forms of Magnesium in Soils of Four Parent Material (Rhodic Paleudults, Rhodic Tropudalts, Oxic Tropudalts, and Aquatic tropossament). Journal of Soil Science, 4, 71-76. https://doi.org/10.5897//SSEM12.082

[35] Abdallah, F., Noumi, Z., Touzard, B., Belgacem, A.O., Neffati, M. and Chelab, M. (2008). The Influence of Acacia tortilis (Forssk) subsp. Raddiana (savi) and Livestock Grazing on Grass Species Composition, Yield and Soil Nutrients in Arid Environments of South Tunisia. Floro, 203, 116-125.

https://doi.org/10.1016/j.flora.2007.02.002

[36] Magandana, T.P. (2016) Effect of Acacia Karoo Encroachment on Grass Production in the Semi-Arid Savannas of the Eastern Cape, South Africa. M.Sc. Thesis, University of Fort Hare, Alice.

[37] Abule, E., Smit, G.N. and Snyman, H.A. (2005) The Influence of Woody Plants and Livestock Grazing on Grass Species Composition, Yield and Soil Nutrients in the Middle Awash Valley of Ethiopia. Journal of Arid Environments, 60, 343-358.

https://doi.org/10.1016/j.jaridenv.2004.04.006

[38] Hagos, M.G. and Smit, G.T. (2005) Soil Enrichment by Acacia mellifera subsp. Detinens on Nutrient Poor Sandy Soils in a Semi-Arid Southern African Savannah. Journal of Arid Environments, 61, 47-59.

https://doi.org/10.1016/j.jaridenv.2004.08.003 